\title{
Gawęda radiowa - dzieło mistrzów mikrofonu (na przykładzie wybranych audycji Rozgłośni Polskiej RWE)
}

\author{
Profesor Barbarze Bogołębskiej, \\ ze wspomnieniem dawnych mistrzów słowa
}

\section{Uwagi wstępne}

Przywołany tu termin „gawędy radiowej” - gatunku zanikającego we współczesnych mediach - obecny był w radiofonii od początku jej istnienia, choć przywoływano go często zamiennie z takimi określeniami gatunkowymi jak „pogadanka” czy „felieton”. Podobne pomieszanie pojęć występowało również w innych przypadkach - na przykład recenzje Jerzego Stempowskiego, nadawane w Rozgłośni Polskiej RWE w latach 1961-1968 zapowiadane były często również jako „pogadanki” bądź „felietony”. Świadczyć to może zarówno o niedostatkach świadomości genologicznej redaktorów, jak i o pokrewieństwie tych gatunków.

Według Stefanii Skwarczyńskiej, istniejące w genologii „twory trojakie”: przedmiot genologiczny - odzwierciedlające je poznawczo pojęcie genologiczne - i nazwa genologiczna muszą być ze sobą skorelowane. Zgodnie z jej postulatem „nauka musi postawić pewne warunki poprawności co do konstrukcji i co do ich fungowania - aby je móc dopuścić w swój obręb”". Spróbujmy zatem, na przykładach zaczerpniętych z programu monachijskiej rozgłośni - kontynuatorki, zwłaszcza w pierwszych dziesięcioleciach działalności, etosu i tradycji radia międzywojennego, dookreślić cechy gatunkowe gawędy radiowej.

* Dr hab., prof UŁ, Uniwersytet Łódzki, Wydział Filologiczny, Katedra Dziennikarstwa i Komunikacji Społecznej, e-mail: konrad.tatarowski@uni.lodz.pl

1 S. Skwarczyńska, Niedostrzeżony problem podstawowy genologii, w: Problemy teorii literatury, wybór prac H. Markiewicz, Ossolineum, Wrocław 1967, s. 147. 
Gawęda, zanim stała się gatunkiem literackim, wyrosła z tradycji ustnej, ludowej. Jak podaje Słownik terminologii medialnej,

[w]yróżnia go [gawędę jako gatunek epiki] wszechwładna obecność i pozycja narratora, czerpiącego wiedzę o zdarzeniach z autopsji bądź od ich uczestników lub świadków. Narrator nie respektuje chronologii wydarzeń i wprowadza wątki anegdotyczne i dygresje, prezentuje subiektywny punkt widzenia [...]. Niektóre cechy gawędy (narracyjność, subiektywność, dygresyjność, luźna kompozycja, funkcja konatywna) są łatwo rozpoznawalne również w felietonie $[\ldots]^{2}$.

W odróżnieniu od gawędy literackiej - która obrosła w obszerną literaturę ${ }^{3}$ - jej radiową odmianę wyróżnia tożsamość autora i narratora. Cechą literackiej odmiany gawędy jest zaś „świadomie założony dystans artystyczny autora do narratora - pośrednika epickiego [...] stojącego poniżej intelektualnego i kulturalnego poziomu autora"4, co umożliwia wykorzystywanie tej formy narracji również do celów parodystycznych czy groteskowych, czego przykłady odnajdujemy w pisarstwie Mikołaja Gogola czy Witolda Gombrowicza.

W radiu autor sam wygłasza swój monolog, odwołując się do własnych doświadczeń i obserwacji, a tym samym - mówiąc obrazowo - swoją „autorską pieczęcią" uwiarygodnia przekazywane treści. A także, co bardzo istotne, konkretyzuje, we własny i niepowtarzalny sposób - sięgając do terminologii Romana Ingardena ${ }^{5}$ - warstwę językowo-brzmieniową dzieła. Ten sam tekst wydrukowany w prasie czy w książce owe szczególne właściwości zatraca, choć zachowuje swoją specyfikę stylistyczno-kompozycyjną.

\section{Radiowe gawędy Zygmunta Nowakowskiego}

Radiowe gawędy Zygmunta Nowakowskiego mieściłyby się w odmianie gatunkowej gawędy historycznej czy historyczno-literackiej, poświęcone były władcom Polski bądź ludziom pióra, od Mikołaja Reja po Stanisława Wyspiańskiego i Stefana Żeromskiego. Nadawane były od początku działalności Rozgłośni Polskiej RWE w 1952 roku aż do początku lat 60. (pisarz zmarł w 1963 roku w Londynie). Nowakowski dążył do „uradiowienia” swoich wypowiedzi, dostosowania ich do potrzeb i percepcji słuchacza. Służyć miał temu „gawędziarski” styl, swobodny, potoczysty, dygresyjny.

2 Słownik terminologii medialnej, red. W. Pisarek, Universitas, Kraków 2006, s. 67.

3 Zob. B. Makowski, Gawęda, w: Słownik rodzajów i gatunków literackich, red. G. Gazda, S. Tynecka-Makowska, Universitas, Kraków 2006, s. 270-273.

4 Tamże, s. 271.

5 Zob. R. Ingarden, Z teorii dzieła literackiego, w: Problemy..., s. 7-59. 
Świat przedstawiony w gawędzie, zgodnie $\mathrm{z}$ regułami tego gatunku, musi być maksymalnie zbliżony do słuchacza. Służy temu zarówno cytowanie historycznych źródeł, jak i fragmentów utworów omawianych pisarzy wraz z ich objaśnianiem. Narrator gawędy z reguły przedstawia się jako uczestnik zdarzeń, o których opowiada. Nowakowski, rzecz jasna, nie był świadkiem chrztu Polski ani nie towarzyszył Mikołajowi Rejowi przy pisaniu Figlików, ale za to w obu radiowych cyklach, historycznym i literackim, wykazywał ogromne osobiste zaangażowanie i pasję wobec omawianych tematów.

Gawędy pod dębem Nowakowskiego, opublikowane później w książce wydanej w Londynie w 1966 roku z przedmową Leopolda Kielanowskiego, miały charakter historyczny i w ramówce programowej Głosu Wolnej Polski widniały pod tytułem History by Radio. Nadawane były w 15-minutowych odcinkach od 19 grudnia 1952 roku do czerwca 1956 roku. Był to cykl 177 pogadanek radiowych, obejmujących okres historii Polski od Mieszka I do Powstania Listopadowego i Wielkiej Emigracji.

Oto co mówił o nich na radiowej antenie i pisał we wspomnianej książce Kielanowski:

Gawędy Nowakowskiego to jakby listy, pisane do ukochanej... na klęczkach. [...] powstały w latach najczarniejszej nocy stalinowskiej, zapadłej nad naszym krajem; w latach, gdy przysłowiowa „żelazna kurtyna” oddzieliła szczelnie Polskę od Zachodu, a w kraju więzienia były pełne ludzi, których jedynym przestępstwem była miłość do ojczyzny ${ }^{6}$.

Omawiając literackie i antenowe walory gawęd Nowakowskiego jako tekstów przynależących do języka mówionego, Kielanowski pisał:

Rytmika zdań, układ słów, dobór określeń pod względem fonetycznych walorów słowa, narastanie i opadanie kadencji mowy, zgodnej z psychofizjologicznymi prawami żywego słowa - wszystkie te elementy tworzyły tekst, stworzony przede wszystkim do głośniej wypowiedzi ${ }^{7}$.

Kontynuacją tego cyklu były audycje nadawane pod tytułem Literature by $R a$ dio. Ich autor nadał im tytuł Stowo polskie nasz chleb niepowszedni, który nie zawsze pojawiał się $\mathrm{w}$ radiowych zapowiedziach. Audycje $\mathrm{z}$ tego cyklu nadawane były - również w 15-minutowych odcinkach - w programie Rozgłośni Polskiej od 24 czerwca 1956 roku. Cykl zainicjowała gawęda pod tytułem Początek mowy polskiej, bohaterem ostatniej z nich był Michał Bałucki.

6 L. Kielanowski, Wieczory pod dębem, „Na Antenie” 1965, nr 33, s. 6.

7 Tamże. 
Audycja zapowiadana była najczęściej jako „radiowe gawędy o historii literatury polskiej”, czasem z cieplejszym i bardziej osobistym akcentem:

A teraz, proszę Państwa, Zygmunt Nowakowski, ulubiony felietonista i gawędziarz emigracji. Jak co niedzieli, tak i dzisiaj, ze swego londyńskiego mieszkanka poprowadzi literacką gawędę przy kominku. Tytuł: „Słoneczko śliczne oko”, czyli o poezji lwowiaka, Szymona Szymonowicza (zapowiedź z 20.01.1957).

Nowakowski rozpoczął cykl od gawęd o życiu i twórczości kronikarzy (Kadłubek, Janko z Czarnkowa, Długosz i inni) oraz pierwszych pisarzy polskich - od Biernata z Lublina (2.09.1956), poprzez Reja, Kochanowskiego, Szymonowicza, później Kniaźnina i Franciszka Karpińskiego (2.03.1958), Fredrę i wielkich romantyków (od maja 1958 roku aż po jesień roku 1960) - aż do twórców z końca XIX i początków XX wieku (Sienkiewicz, Reymont, Żeromski, Wyspiański).

\section{Alfred Zbyszewski jako autor radiowych gawęd}

Inną odmianę gawędy - tematycznie osadzonej we współczesności, bardziej zbliżonej do felietonu, bliskiej formule „listu z podróży” bądź nawet reportażu - przedstawiał na antenie RWE Wacław Alfred Zbyszewski, współpracownik paryskiej „Kultury”, a wcześniej również korespondent „Głosu Ameryki”.

Jego Wędrówki po Europie (My journey through Europe) pojawiły się w programie Rozgłośni 2 września 1958 roku. Przez pierwsze lata nadawał je raz w tygodniu (we wtorki, po 15 minut), później, od 1960 roku, dwa razy w tygodniu, ale w krótszych, 10-minutowych odcinkach. Gawędy Zbyszewskiego były nadawane aż do końca lat 70., a zatem przez ponad dwadzieścia lat.

Mówił w nich, zgodnie z tytułem, o swoich podróżach do różnych krajów europejskich - i o tym, co wydało mu się tam na tyle godne uwagi, by zajmować swymi obserwacjami polskich słuchaczy. A zatem - o modzie, o tym, jak i gdzie się pracuje, o polityce rolnej i przemysłowej, o architekturze, zabytkach, galeriach sztuki. O specjałach kulinarnych, polityce i gospodarce, o turystyce, malarstwie, uczelniach i życiu intelektualnym. Mówił ciekawie, z pasją, bardziej z pozycji obserwatora niż uczestnika zachodniego świata. Najwięcej czasu poświęcił Francji i Paryżowi, Anglii i jej stolicy - ale także takim krajom, jak Szwajcaria, Grecja, Włochy, Turcja, Holandia.

\section{Tadeusz Nowakowski - (ostatni?) mistrz radiowej gawędy}

Kontynuatorem radiowej gawędy - zainicjowanej przez Zygmunta Nowakowskiego - był też, w ostatnim okresie działalności Rozgłośni Polskiej RWE, Tadeusz Nowakowski. Już po przejściu na radiową emeryturę raz w tygodniu wygłaszał gawędy Przy kawiarnianym stoliku. Charakterystyczna dla niego dygresyjność, przywoły- 
wanie odległych często wspomnień na zasadzie skojarzeń i asocjacji, niejednokrotnie uzasadnionych jedynie osobistymi doświadczeniami autora, poczucie humoru i gęste wplatanie anegdot decydowały o klimacie i specyfice tych 15-minutowych audycji. Gawędy Tadeusza - w odróżnieniu od omawianych wcześniej historycznych bądź historyczno-literackich audycji Zygmunta Nowakowskiego - były wypowiedziami wpisanymi w krąg biografii i doświadczeń autora, jego świata wartości, osobistych refleksji. Te ostatnie, rzecz jasna, decydowały również o specyfice gawęd Zygmunta, ale osadzone były na materiale historycznym i źródłowym, odczytywanym niejako z perspektywy jednostkowego, autorskiego punktu widzenia.

Audycje Przy kawiarnianym stoliku prowadził Nowakowski od 9 lutego 1977 roku, w pierwszych latach nieregularnie. Początkowo były to rozmowy z zaproszonymi gośćmi - z Janem Kottem rozmawiał o teatrze (8.06.1977), z Lidią Ciołkoszową o polskim ruchu socjalistycznym (8.07.1977), z Józefem Czapskim o jego malarstwie (1.01.1979). W miarę upływu czasu coraz częściej audycje stawały się swoistą sceną jednego aktora - Nowakowskiego, który dzielił się ze słuchaczami swoimi fascynacjami literackimi (o poezji Herberta, 22.05.1988, o Brunonie Schulzu, 17.05.1992), przemyśleniami politycznymi (Porozmawiajmy o Chruszczowie, 25.09.1988), mówił o sobie (Czy Olsztyński to Olsztyński ${ }^{8}$, 27.09.1981) bądź też o instytucjach, miejscach i ludziach, z którymi był związany (Wokół inauguracji Rozgłośni, gawęda wygłoszona w związku z 40-leciem Rozgłośni Polskij RWE, 22.03.1992). Ostatnia, 150. audycja Przy kawiarnianym stoliku (pt. Czy Pan mówi po poznańsku) została wyemitowana w programie 6 listopada 1993 roku - a zatem pół roku przed zamknięciem działalności monachijskiej Rozgłośni.

Charakter bardzo osobisty, a zarazem kunsztowny i intrygujący dla postronnego odbiorcy, mają jego wspomnienia przyjaciół, którzy odeszli z tego świata - Wojciecha Trojanowskiego (26.02.1988), a także wcześniejsze o kilkanaście lat gawędy o Zygmuncie Nowakowskim (17.11.1963) i Czesławie Straszewiczu (20.10.1963). W pośmiertnym wspomnieniu o Nowakowskim, opublikowanym w londyńskich „Wiadomościach”, Tadeusz Nowakowski przytaczał jego słowa: „Ciekaw jestem, czy znajdzie się ktoś na emigracji, kto potrafi choć kilka słów sklecić na moim grobem. Czuję, że sam zrobiłbym to najlepiej” - i komentuje je: „To prawda. Najpiękniejsze wspomnienie o Panu Zygmuncie wygłosiłby tylko jeden mówca złotousty, mistrz powściągliwego patosu, bard sentymentalny, lirnik serdeczny, on sam - Zygmunt Nowakowski"”.

Można śmiało powiedzieć, że po Zygmuncie Nowakowskim - choć przecież nie łączyło ich żadne pokrewieństwo - odziedziczył owe zdolności Tadeusz. Oto jak żegnał swojego radiowego przyjaciela, Czesława Straszewicza:

8 „Tadeusz Olsztyński” był radiowym pseudonimem Nowakowskiego, utworzonym od miejsca jego urodzenia: Olsztyna.

9 T. Nowakowski, Extra Cracoviam non est vita, „Wiadomości” 1963, nr 49(923), s. 1.

10 Tamże. 
Czesio nie żyje! Jeszcze mi w uszach dźwięczy jego głos. Jeszcze słyszę jego serdeczny chichocik z gatunku „z cicha pękł”. Widzę jego dobrotliwe, przyjaźnie błyszczące oczy, które kojarzą mi się z obrazkiem znanym z dzieciństwa: łagodny pies bernardyn z beczułką koniaku pod szyją śpieszy na ratunek ${ }^{11}$.

Niezwykłe zestawienie, porównanie, które znajduje uzasadnienie jedynie w zakamarkach pamięci autora - narratora. W dalszych fragmentach swojej wypowiedzi przybliżał on postać Straszewicza, z którym pozostawał w bliskich i serdecznych relacjach:

Przez kilka lat siedzieliśmy w biurze, „glebae adscripti”, przy tym samym biurku, do tego samego wiosła przykuci. Mieszkaliśmy w tym samym domu, na piątym piętrze, oddzieleni cieniutką ścianką, przez którą słychać było każde słowo. Mieliśmy nawet nieduży balkonik na spółkę, przepołowiony żaglowym płótnem, na którym w promieniach słońca skrzyły się bateria pustych butelek po tym niezawodnym lekarstwie, jakiego przezorny Polak na obczyźnie zażywa przeciwko wynarodowieniu się $e^{12}$.

Przybliżał jego sylwetkę w różnych sytuacjach życiowych, czasem śmiesznych, czasem wręcz groteskowych - na przykład wtedy, gdy opowiadał, w jakich okolicznościach pozbawiono Straszewicza pracy magazyniera w fabryce w Urugwaju. Kiedy przeprowadzano tam redukcję zatrudnienia, na liście zwolnionych znalazł się też autor Turystów $z$ bocianich gniazd. W uzasadnieniu decyzji napisano: „Ceslao Straszewicz - analfabeta»... Jestem jedynym pisarzem polskim - przechwalał się ze śmiechem Czesio - któremu zaświadczono na piśmie, że jest analfabetą!"13. Po przytoczeniu tej anegdoty Nowakowski przeszedł do błyskotliwego i erudycyjnego - ale utrzymanego w swobodnym i obrazowym tonie - omówienia pisarstwa przyjaciela, kończąc gawędę w ciemnych tonacjach, wspominając śmiertelną chorobę pisarza i okoliczności jego wyjazdu - krótko przed śmiercią - z Monachium do Urugwaju oraz żegnając go „starym a prostym, od pokoleń niezmiennym pozdrowieniem, jakim się żegnają Polacy, rozsiani po obcych lądach: «Śpij, kolego, w ciemnym grobie, niech się Polska przyśni Tobie»"14.

Czy Tadeusz Nowakowski był ostatnim mistrzem radiowej gawędy? Tego oczywiście, nikt stwierdzić nie może, bo przyszłość jest otwartą kartą. Ale do chwili obecnej kontynuatorów tego typu wypowiedzi, takiego sposobu nawiązywania kontaktu ze słuchaczami, takiej umiejętności wciągnięcia ich w autorski monolog

11 T. Nowakowski, Czesio, „Na Antenie” 1963, nr 7, s. 4.

12 Tamże.

13 Tamże.

14 Tamże. 
- nie widać ani w polskim radiu, ani w telewizji, bo mistrzowie gawędy radiowej (wzbogaconej o element wizualny i ilustracyjny, choć słowo nadal pełniło dominującą rolę) na szklanym ekranie również się pojawiali.

\section{Mistrzowie gawędy w polskim radiu i telewizji - Jerzy Waldorff i Bogusław Kaczyński}

Jerzy Waldorff, pisarz i znawca muzyki, był etatowym pracownikiem Polskiego Radia aż do 1976 roku, kiedy zwolniono go z pracy po podpisaniu przez niego głośnego „Listu 59” przeciwko zmianom w konstytucji PRL, które wpisywały do niej nierozerwalny i wieczysty sojusz z ZSRR oraz przewodnią rolę PZPR w PRL. Na radiowej antenie prowadził szereg audycji o muzyce, sławę i popularność zdobył jednak dzięki telewizji. Prowadził w niej programy o wielkich postaciach z przeszłości - w latach 60. cykl Spotkania z cieniem, w którym przypominał m.in. Hankę Ordonównę, Jana Kiepurę i inne gwiazdy wokalistyki, zaś później, w latach 70., cykl programów $Z$ muzyka przez lata poświęconych twórcom muzyki poważnej, jak Karol Szymanowski, Stanisław Moniuszko czy bracia Wieniawscy. Swoją działalność kontynuował jeszcze w latach 90. cyklem programów Połowy na rzece wspomnień, mówiących o wydarzeniach muzycznych i wielkich postaciach ze świata muzyki od XIX wielu aż po okres międzywojenny.

Jego programy to były swoiste „spektakle jednego aktora”, zdominowane przez narratora obdarzonego charakterystycznym, wysokim głosem, szczególnie modulowanym. Towarzyszył mu w nich przez kilka lat jego ukochany jamnik, Puzon, a także elegancka laska zakończona srebrną gałką. Mówił potoczyście, barwnie, sięgając często do dygresji i anegdot, a przy okazji wykazując się ogromną wiedzą i erudycją.

Kontynuatorem jego działalności radiowej i telewizyjnej był Bogusław Kaczyński, który od 1970 roku był komentatorem muzycznym w polskim radiu i telewizji. Również on - w prowadzonych przez siebie telewizyjnych programach Qui pro quo w latach 1974-1978 i później w Zaczarowanym świecie operetki - był postacią wiodącą i w długich monologach przybliżał widzom świat gwiazd wokalistyki, kompozytorów i autorów librett, ich impresariów, a także wprowadzał widza w klimaty oraz specyfikę świata sztuki i życia artystycznego. Można przypuszczać, że Waldorff i Kaczyński swoją pasją, a także zaangażowaniem zdołali „zarazić” wielu późniejszych bywalców sal koncertowych i teatrów muzycznych.

\section{Uwagi końcowe}

Gawęda radiowa, a także jej telewizyjna kontynuacja należą do gatunków zanikających. Nie ma na nią miejsca w ramówkach programowych publicznych, a także prywatnych, mediów elektronicznych. W programach publicystycznych i kultu- 
ralnych dominują formy krótkie, komentarzowe lub felietonowe, jeżeli zaś jakiś temat rozwijany jest dłużej, to $\mathrm{z}$ reguły $\mathrm{w}$ formie rozmowy lub dyskusji kilkorga uczestników. W zuniformizowanym, zestandaryzowanym w sposobie przekazu, choć zróżnicowanym tematycznie i ideowo świecie mediów, zanika humanistyczna, jednostkowa perspektywa. Przyczyn tego stanu rzeczy może być kilka i można by ten temat rozwinąć do rozmiaru osobnego artykułu. Tutaj jedynie go sygnalizuję, by skonstatować, że zarówno w radiofonii, jak i w telewizji współczesnej zanikają dłuższe, spersonalizowane, subiektywne formy wypowiedzi, a wraz z nimi giną wyraziste medialne osobowości.

\title{
Bibliografia
}

Ingarden R., Z teorii dzieła literackiego, w: Problemy teorii literatury, wybór prac H. Markiewicz, t. 2, Ossolineum, Wrocław 1967, s. 7-59.

Kielanowski L., Wieczory pod dębem, „Na Antenie” 1965, nr 33, s. 6.

Makowski B., Gawęda, w: Słownik rodzajów i gatunków literackich, red. G. Gazda, S. Tynecka-Makowska, Universitas, Kraków 2006, s. 270-273.

Nowakowski N., Extra Cracoviam non est vita, „Wiadomości” 1963, nr 49(923), s. 1. Nowakowski T., Czesio, „Na Antenie” 1963, nr 7, s. 4.

Skwarczyńska S., Niedostrzeżony problem podstawowy genologii, w: Problemy teorii literatury, wybór prac H. Markiewicz, Ossolineum, Wrocław 1967, s. 145-164. Słownik terminologii medialnej, red. W. Pisarek, Universitas, Kraków 2006.

Konrad W. Tatarowski

\section{Gawęda radiowa - dzieło mistrzów mikrofonu (na przykładzie wybranych audycji Rozgłośni Polskiej RWE)}

\author{
Streszczenie
}

Artykuł zawiera definicję i charakterystykę gawędy radiowej w porównaniu z gawędą literacką oraz omówienie różnych odmian gatunkowych gawędy radiowej na przykładach twórczości mikrofonowej Zygmunta Nowakowskiego, Alfreda Zby- 
szewskiego i Tadeusza Nowakowskiego, a także telewizyjnych programów Jerzego Waldorffa i Bogusława Kaczyńskiego.

Słowa kluczowe: gawęda radiowa, gatunki radiowe, pisarze w Rozgłośni Polskiej RWE.

\title{
Radio Chat: A Work of Radio Masters (Based on Programs by Polish Broadcaster RFE)
}

\author{
Summary
}

The article's goal is to distinct and characterize both - "Radio Chat" and "Literary Chat", as well as discuss various genres of "variety shows", recalling examples of radio pieces created by Zygmunt Nowakowski, Alfred Zbyszewski, Tadeusz Nowakowski, as well as TV programs by Jerzy Waldorf and Bogusław Kaczynski.

Keywords: radio chat, radio genres, Polish Brodcaster RFE.

Konrad Witold Tatarowski - dr hab., prof. UŁ, literaturoznawca i medioznawca, publicysta, poeta i krytyk literacki. Autor książek: Światło w ciemności (1993, zbiór poetycki), Literatura i pisarze w programie Rozgłośni Polskiej RWE (2005), Aksjologia i polityka w pisarstwie i działalności Jana Nowaka-Jeziorańskiego (2010), Niezależna literatura i dziennikarstwo przed 1989 rokiem. Idee - ludzie - spory (2016), Liryka i polityka. Jacek Bierezin, Zbigniew Dominiak, Zdzisław Jaskuła, Witold Sułkowski - o twórczości poetów podziemnego pisma „Puls” (współautorka R. Nolbrzak, 2019) oraz kilkudziesięciu artykułów w monografiach i czasopismach naukowych na temat życia literackiego emigracji, Rozgłośni Polskiej RWE, „drugiego obiegu" wydawniczego w PRL oraz literatury XX i XXI wieku. Autor licznych publikacji w czasopismach emigracyjnych i krajowych, a także słuchowisk i reportaży radiowych. 